(b) For patients with pronounced clinical features of acute pyelonephritis where rapid control to limit renal damage is desirable.

(c) For patients known to have extensive renal damage where there is a danger of infection precipitating renal failure as well as extending the renal lesion.

(d) Post-operative patients where oral therapy is impracticable or where absorption is in doubt.

Finally, we do not wish to claim that ampicillin is superior to all other drugs in the treatment of urinary tract infection. More comparative trials are needed before the superiority of one antibiotic over another can be established.

\section{REFERENCES}

Anderson, K. N., Kennedy, R. P., Plorde, J. J., Shulman, J. A., and Petersdorf, R. G. (1964): J. Amer. med. Ass., 187, 555.

BrumfitT, W., and Percival, A. (1962): Lancet, i,
Brumfitt, W., Percival, A., and Carter, M. R (1962): Lancet, i, 130.

BRUmfits, W., and Percival, A. (1964): 2nd Intere national Pyelonephritis Symposium. To be published.

Brumfitt, W., Williams, J. D., Leigh, D. A., and Percival, A. (1964): 2nd International Pyelone? phritis Symposium. To be published.

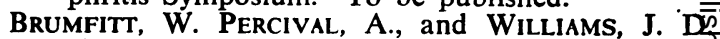
(1964): Brit. J. clin. Pract., 18, 503.

HuBER, H. G. (1936): Munchen. med. Woçhenschr 83, 2014.

KASS, E. H. (1955): Amer. J. Med., 18, 764.

KenNy, M., Johnson, F. D., and von Haebler, (1937): Lancet, ii, 119.

Mond, N. C., Percival, A., Williams, J. D., ang BRUMFITT, W. (1964): In the press.

Richakd, W. A., RisS, E., KASS, E. H., and FinLAND M. (1955): Arch. intern. Med., 96, 437.

Rolinson, G. N., and STEvens, S. (1961): Brit med. J., ii, 191.

Rosenheim, M. L. (1935): Lancet, i, 1032.

Trafford, J. A. P., Mclaren, D. M., Lillicrap? D. A., Barnes, R. D. S., Houston, J. C., an KNoX, R. (1962): Lancet, i, 987.

TURCK, M., BROWDER, A. A., LINDERMEYER, R. I? Brown, N. K., ANDERSON, K. N., and PeTERSDORF, R. G. (1962): New Engl. J. med., 267, 999

\title{
TREATMENT OF URINARY TRACT INFECTIONS WITH AMPICILLIN
}

\author{
Peter Naumann \\ From the Institute of Clinical Bacteriology and \\ Serology of the University of Hamburg.
}

(Director: Professor G. B. Roemer).

THE therapeutic evaluation of a new antibiotic should not be carried out solely according to clinical criteria. The course of a bacterial infection depends on too many individual factors and imponderables. The therapeutic value of an antibiotic cannot, therefore always be assessed objectively by comparing clinically cured or improved cases with those who failed to respond. After all, a not inconsiderable number of infections is cured without any or with only inadequate therapy and may then be quoted as evidence in favour of a preparation which actually is ineffective. On the other hand, failure to respond may be wrongly ascribed to an "ineffective" antibiotic, even though the bacterial process has been controlled, or is capable of being controlled, provided the drug is given in adequately high doses. "Clinical cure" is a complex event which depends on the defen- sive potential of the body as a whole, and is not always easy to make a true assess ment of the part played by the antibiolic-both in the cured case and in that which fails to respond. This applies particularly to infections of the urinary tract, for even aftee successful eradication of one organism re infection by an unrelated bacterial strairf frequently results in apparent failure of therapys For this reason assessment of a drug such as ampicillin should not be based on the number of "clinical cures", but primarily on the cons" sideration whether the bacteriological effecf has been attained which should. be expected from this antibiotic.

\section{Present Series}

Using the bacteriological examination of the urine to diagnose the presence of infec tion, an attempt has been made during 196 点 
to evaluate the therapeutic action of ampicillin in infections of the urinary tract. Out of a total of 4,340 urines submitted for investigation 1,221 samples were used in which clinical picture, pyuria and microscopical findings confirmed the diagnosis of urinary tract infection.

In $1,004(82.2 \%)$ of these "infected" urines Esch. coli and coliform organisms were identified either mixed or in pure culture in 667 instances (66.4\%), Proteus spp. in $362(36.0 \%)$, Pseudomonas pyocyanea in $103(7.3 \%)$ and enterococci in $283(28.1 \%)$. Staphylococcus aureus was found in 38 cases, i.e. in $3.1 \%$ These findings confirm that urinary tract infections are primarily caused by organisms which compose the physiological intestinal flora, whilst the classical suppurative organisms play a comparatively minor role.

In 1,415 of these bacterial strains the bacteriostatic and bactericidal activity of ampicillin was investigated and compared with that of tetracycline, chloramphenicol and colistin in quantitative serial tube dilution tests. The evaluation of the minimal inhibitory concentrations (M.I.C.) which were obtained as "sensitive" or "resistant" was deliberately related to antibiotic concentrations which could be attained in blood and tissues. The high ampicillin urine concentrations which according to our own investigations range up to $2,600 \mu \mathrm{g} . / \mathrm{ml}$. were disregarded in this context, for these concentrations apply only to the lumen of the urinary tract and are not effective in its deeper tissue layers, nor in the renal tissues. Especially in chronic urinary tract infections and in pyelonephritis the inflammatory processes are not restricted to the lumen and the mucous membrane surface. Organisms located within the kidney tissue are only accessible via the blood stream, i.e. the antibiotic concentrations in the serum and tissues are relevant (Brit. med. J. Editorial 1961). Even though symptomatic improvement of pyuria and bacteriuria can be obtained via the urinary tract (e.g. with nitrofurantoin or mandelic acid), the effect is usually only intermittent and palliative. Indeed, by purely symptomatic treatment and by suppressing the acute inflammatory processes in the lumen of the tract the chronic processes in the deeper tissues may actually be promoted. Relapses after discontinuing such therapy are not uncommon (Bunn, 1962). Effective cure of urinary tract infections-of decisive importance for the future well-being of the patient-thus depends on antibacterial tissue levels, i.e. concentrations which are effective at the site of infection.

Brumfitt, Percival and Carter (1962) have emphasized that the aim of treatment must not be solely the destruction of bacteria in the urine, but primarily antibacterial action on the causative organism at the site of infection.

On the basis of the attainable blood and tissue levels (Brumfitt et al. 1962, Knudsen, Rolinson and Stevens 1961, Naumann 1962, Rolinson 1963, Sökeland 1963) we have therefore, in agreement with Trafford, McLaren, Lillicrap, Houston, Barnes and Knox, (1962), fixed the limits of sensitivity at an M.I.C. of $3.125 \mu \mathrm{g}$./ampicillin $/ \mathrm{ml}$. Organisms which required higher concentrations for their inhibition are described as "resistant".

\section{Results}

Using this definition, all 103 tested strains of Ps. pyocyanea were absolutely resistant to ampicillin and had therefore to be treatedo with colistin. Out of 667 Esch. coli strains and coliform organisms only ten per cent showed an M.I.C. of $3.125 \mu \mathrm{g}$. ampicillin and below. Our investigations confirmed the findings of (Stewart, Coles, Nixon and Holt 1963 and of Daikos, Kontomichalou and Paradelis 1963) that the majority of these strains could only be inhibited by higher concentrations than could be definitely attained in the tissues. This does not bear out the findings of other authors (Auhagen et al. 1962; Barber and Waterworth, 1962; Rolinson, 1963; Trafford et al. 1962) who reported a good in vitro action of ampicillin on Esch. coli. Possibly this difference is associated with the different origin of the Esch. coli strains used by different investigators. The strains which were investigated here were cultured from materials obtained in the course of urological investigations and confirmed by several tests as true causative organisms of urinary infections, mostly chronic. Seventy per cent of these Esch. coli strains were sensitive to tetracycline or chloramphenicol; the remaining $28 \%$ had to be treated with colistin.

On the other hand, ampicillin showed an outstanding effect on proteus and enterococci. Out of 362 proteus strains $75 \%$ of which were resistant to chloramphenicol and almost $100 \%$ to tetracycline, $65 \%$ were inhibited by ampicillin concentrations which could be attained in the tissues. For most proteus 
strains even bactericidal concentrations could be attained with therapeutic doses. Ampicillinresistant were predominantly the nonswarming strains of proteus $(34.5 \%)$.

All 283 strains of enterococci which were tested were found to be sensitive to ampicillin, although absolute bactericidal action was not achieved owing to persistent survival of individual organisms.

These findings fully agree with the results obtained by other authors (Auhagen 1962, Barber and Waterworth 1962, Brumfitt et al., 1962, Rolinson 1963, Rutenburg 1962, Sökeland 1963, Stewart et al., 1961, Trafford et al., 1962) and define infections with proteus and enterococci as the primary field of indication for ampicillin. Not only does it supplant here toxic preparations of the neomycin and kanamycin groups, but with this specific activity against proteus and enterococci it also closes an important gap in the range of the broad spectrum antibiotics.

In order to ensure the full therapeutic use of ampicillin for its proper field of indications adequate doses are essential. For adults the minimal dosage by mouth was $4 \mathrm{~g}$. per day (approx. $65 \mathrm{mg}$. $/ \mathrm{kg}$. per day); for less sensitive organisms the amount was increased up to $20 \mathrm{~g}$. per day ( $400 \mathrm{mg}$. $/ \mathrm{kg}$. per day). Apart from diarrhoea and mild gastrointestinal disturbances no toxic side effects were observed. There was no need to discontinue the preparation in any case. In some cases with severe urinary sepsis caused by proteus or enterococci where oral application was not possible intravenous injection (500 to 1,000 mg. four times daily) of a five per cent solution showed good results. With repeated intravenous adminstration of $500 \mathrm{mg}$. every six hours the mean blood levels were found to be $9.6 \mu \mathrm{g}$. $/ \mathrm{ml}$. after one hour, $2.7 \mu \mathrm{g}$. $/ \mathrm{ml}$. after two hours, $0.6 \mu \mathrm{g} . / \mathrm{ml}$. after four hours and 0.15 $\mu \mathrm{g} . / \mathrm{ml}$. after six hours. In renal insufficiency associated with impaired excretion (nonprotein nitrogen $90 \mathrm{mg} . \%$ ) considerably higher levels of $32 \mu \mathrm{g} . / \mathrm{ml}$. after one hour and $13 \mu \mathrm{g} . / \mathrm{ml}$. after six hours were obtained. (Table I).

In uncomplicated urinary infections with "sensitive" strains of proteus and enterococci excellent bacteriological effects could be demonstrated in $84 \%$ of all cases which were followed up. It is true that in some instances the infecting organism changed (mostly to Esch. coli or Ps. pyocyanea), and clinical cure was delayed in this way. When calculi were present in the kidney or bladder, or tumours

\section{TABLE I}

Serum Concentrations in $\mu \mathrm{g} . / \mathrm{ml}$. Following Intra@ venous Adminstration of $500 \mathrm{mg}$. Ampicillin-Sodium.

\begin{tabular}{|c|c|c|c|c|c|}
\hline \multirow[b]{2}{*}{$\begin{array}{l}\text { Normal Renal } \\
\text { Function }\end{array}$} & \multicolumn{4}{|c|}{ Hours after last injection } & \\
\hline & 9.6 & 2.7 & 0.6 & 0.15 & $\mu \mathrm{g} . / \mathrm{ml}$ \\
\hline $\begin{array}{l}\text { Renal } \\
\text { Insufficiency } \\
\text { (non protein > }\end{array}$ & $\begin{array}{c}32.0 \\
\mathrm{~N}=90\end{array}$ & $\begin{array}{l}25.0 \\
\mathrm{ng} \%)\end{array}$ & 21.0 & 13.0 & $\mu \mathrm{g} . /$ \\
\hline
\end{tabular}

or congenital abnormalities were present in the urinary tract, the infection could practically never be suppressed by purely conservative measures. In such cases surgical and chemo f therapeutic measures must supplement eachts other.

Our results have confirmed that for the complex clinical concept of "urinary trac: infections" there can be no universa? therapeutic measure, but at best an optimaL antibiotic for individual causative organisms. With this reservation ampicillin has shown itself as a well tolerated preparation which constitutes a true therapeutic advance in the planned treatment of infections with protegis. and enterococci.

\section{Summary}

One thousand, four hundred and fifteen strains of bacteria, practically all of themp cultivated from urological specimens anco proved to be responsible for urinary trace infections, were tested for sensitivity $t \overrightarrow{\vec{B}}$ ampicillin, using a serial tube dilution test The M.I.C. was realistically interpreted in accordance with ampicillin concentrations. which can be attained in blood and tissues? Using this definition only $10 \%$ of the tested Esch. coli and coliform strains were found to be "sensitive" to ampicillin. Sixty-six point three per cent of 362 strains of proteus (mirabilis and vulgaris) and all 283 strains of enterococci were found to be "sensis tive" (M.I.C. $\leqq 3.125 \mu \mathrm{g} . / \mathrm{ml}$.). One hundre of and three strains of Ps. pyocyanea were com pletely "resistant". Where primarily sensitives bacteria were isolated, the bacteriological result was invariably good, even though clinical re covery could often not be realized owing to $a_{0}^{\omega}$ change in the infecting organism. Given in high doses and for prolonged periods ampicillin ha: proved an excellent antibiotic without any side effects in the treatment of infections with proteus and enterococci. 


\section{REFERENCES}

Acred, P., Brown, M., Turner, D. H., and Wilson, M. J. (1962): Brit. J. Pharmacol., 18, 356.

Auhagen, E., Gloxhuber, Ch., Hecht, G., Knott, Th., Otten, H., Rauenbusch, E., Risse, K. H., Schmid, J., Scholtan, W., and Walter, A. M. (1962): Arzneimittel-Forsch, 12, 791.

Barber, M., and Waterworth, P. M. (1962) $\vdots$ Brit. med. J., i, 1159.

Brumfitt, W., Percival, A., and Carter, M. J. (1962): Lancet, i, 130.

BunN, P. A.: Antimicrobial Agents and Chemotherapy-1962, p. 739, Amer. Soc. Microbiol.

Daikos, G. K., Kontomichalou, P., and Paradelis, A. (1963): Dtsch. med. Wschr., 88, 1678.

EDITORIAL (1961): Brit. med. J., ii, 574.

GARROD, L. P.. (1960): Brit. med. J., i, 527.

Garrod, L. P. (1960): Brit. med. J., ii, 1695.

KNudsen, E. T., Rolinson, G. N., and Stevens, S:. (1961): ibid, ii, 198.

Naumann, P. (1962): Arzneimittel-Forsch., 12, 984.
Naumann, P. (1963): Dtsch. med. Wschr., 88, 165.

NaumanN, P. (1964): Proceedings of IIIrd Internat. Congress of Chemotherapy, Stuttgart, 1963. Stuttgart: Georg Thieme-Verlag. In the press.

Rolinson, G. N., and Stevens, Sh. (1961): Brit. med. J., ii, 191.

Rolinson, G. N. (1964): Proceedings of IIIrd Internat. Congress of Chemotherapy, Stuttgart, 1963. Stuttgart: Georg Thieme-Verlag. In the press.

Rutenburg, A. M., Greenberg, H. L., SchWeinburg. F. B., and Perreault, M. A.: Antimicrobial Agents and Chemotherapy, 1962, p. 748, Amer. Soc. Microbiol.

SöKELAND, J. (1964): Proceedings of IIIrd Internat. Congress of Chemotherapy, Stuttgart, 1963. Stuttgart: Georg Thieme-Verlag. In the press. Stewart, G. T., Coles, H. M. T., NixoN, H. H., and Holt, R. J. (1961): Brit. med. J., ii, 200.

Trafford, J. A. P., Mclaren, D. M., Lillicrap, D. A., Barnes, R. D. S., Houston, J. C., and KNOX, R. (1962): Lancet, i, 987.

\title{
AMPICILLIN AND SULPHADIMIDINE IN TREATMENT OF URINARY TRACT INFECTION
}

\author{
J. C. Gould and Elizabeth EDMond
}

Central Microbiological Laboratories, Edinburgh, 4.

From the bacteriological point of view there is a great difference between the "primary" case of urinary tract infection such as occurs in the young adult with bacteriuria, and the "secondary" or chronic case such as the chronic pyelonephritic who has had much investigation and treatment. In the former the flora is almost invariably simple consisting of Esch. coli; in the latter the flora is frequently complex and many of the infecting strains are resistant to the antibacterial agents commonly used in treatment. The treatment of such cases is less satisfactory, particularly with the sulphonamides.

The primary type of case is however important since successful treatment of such early cases should reduce the incidence of chronic infection. It is important that these early cases be treated effectively to eradicate the infection before irreversible damage has been caused to renal tissue and chronic pyelonephritis becomes inevitable.

The general practitioner and the obstetrician most frequently come into contact with this type of early case. Many use sulphonamides in the treatment of infections of the urinary tract with good results, and since sulphonamides are relatively cheap and familiar to them they tend to be the drugs most frequently used. Some workers have suggested that these results are more apparent than real, and failure to eradicate the infection leads to relapse and the development of chronic disease.

\section{Diagnosis}

The diagnosis of urinary tract infection is particularly important in the young woman, for in our opinion there are more such women treated for non-existent urinary tract infection than who fail to have treatment for an infection which has not been diagnosed. Important in this context is a proper appreciation of quantity and quality of the urinary microflora and the examination of the urine by the bacteriologist should involve an assessment of the following factors:

1. Serial specimens of urine must be examined before treatment to establish that a significant bacteriuria exists. In a number of patients intermittent bacteriuria may lead to 